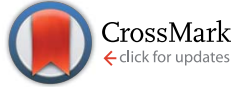

Cite this: RSC Adv., 2015, 5, 85486

Received 7th September 2015 Accepted 30th September 2015

DOI: $10.1039 / c 5 r a 18270 k$

www.rsc.org/advances

\section{Isocyanide substitution reactions at the trans labile sites of an iron(II) $\mathrm{N}$-heterocyclic carbene complex $\uparrow$}

\begin{abstract}
S. Haslinger, ${ }^{a}$ A. C. Lindhorst, ${ }^{a}$ J. W. Kück, ${ }^{a}$ M. Cokoja, ${ }^{\text {b }}$ A. Pöthig ${ }^{c}$ and F. E. Kühn ${ }^{\star a}$
A variety of isocyanide-substituted Fe(॥) N-heterocyclic carbene (NHC) complexes has been synthesized, starting from an $\mathrm{Fe}(॥) \mathrm{NHC}$ complex with an equatorial, tetradentate bis(pyridyl-NHC) ligand (NCCN). Depending on the relative amount of isocyanide used for the reaction either mono(isocyanide)substituted or tri(isocyanide)-substituted Fe(॥) complexes are obtained. In the case of the tri-substituted complexes single crystal X-ray diffraction reveals the dissociation of one of the pyridyl moieties of the tetradentate NCCN ligand, inducing a meridional, tridentate NCC coordination. As an intermediate for the formation of the tri-substituted complexes a cis di $\left(\mathrm{CN}^{t} \mathrm{Bu}\right)$-substituted Fe(॥) complex was identified by NMR spectroscopy. The impact of the isocyanide ligands on the electronic structure of the iron complexes was investigated by cyclic voltammetry, showing an increase in the required potential for the oxidation of $\mathrm{Fe}($ (I) to Fe(III) from $423 \mathrm{mV}$ to up to $1092 \mathrm{mV}$.
\end{abstract}

\section{Introduction}

Iron, the most abundant transition metal, has generated a broad range of chemical applications. ${ }^{1-7}$ The urge to develop environmentally friendly, cheap, and toxicologically unproblematic catalysts further increased the significance of iron coordination compounds in recent years. ${ }^{8-10}$ This development in chemical research was mainly driven by studies on biological and bioinspired systems. ${ }^{11-13}$ With iron active sites playing a crucial role in many biological processes, researchers intended to adapt nature's principles to artificial systems. ${ }^{14}$ Especially in the field of iron-based, bioinspired oxidation catalysis remarkable advances were made in the last decade, leading to a better understanding of reaction mechanisms and to improved catalyst performance. ${ }^{13,15-17}$ A common structural motif of these compounds is the use of polydentate ligands with $\mathrm{N}$ donor atoms as supporting ligands for $\mathrm{Fe}(\mathrm{II})$ and Fe(III) complexes. ${ }^{13,18}$ Furthermore, the successful implementation of N-heterocyclic carbenes (NHCs) as ligands to a range of transition metal-catalyzed reactions also led to a constantly increasing number of reported iron NHC

\footnotetext{
${ }^{a}$ Chair of Inorganic Chemistry/Molecular Catalysis, Technische Universität München (TUM), Department of Chemistry/Catalysis Research Center, Lichtenbergstr. 4, D-85747 Garching bei München, Germany. E-mail: fritz.kuehn@ch.tum.de; Fax: +49 89289 13473; Tel: +49 8928913096

${ }^{b}$ Chair of Inorganic and Organometallic Chemistry, Technische Universität München (TUM), Ernst-Otto-Fischer-Straße 1, D-85747 Garching bei München, Germany

${ }^{c}$ Catalysis Research Center, Technische Universität München (TUM), Ernst-OttoFischer-Straße 1, D-85747 Garching bei München, Germany

$\uparrow$ Electronic supplementary information (ESI) available: Listings of NMR data. CCDC 1422720-1422724. For ESI and crystallographic data in CIF or other electronic format see DOI: $10.1039 / \mathrm{c} 5 \mathrm{ra1} 270 \mathrm{k}$
}

complexes with catalytic activity. ${ }^{\mathbf{8} 19-22}$ Electronic fine-tuning for an improved catalytic performance can be achieved by either variation of the polydentate ligand or by introduction of ligands with specific donor or acceptor properties into accessible coordination sites. ${ }^{23}$ For instance, the impact of axial ligands with diverse electronic properties on the oxygenation reactivity in apical positions has been investigated in some detail. ${ }^{24,25}$

Our group, for example, developed an $\mathrm{Fe}(\mathrm{II})$ oxidation catalyst bearing a tetradentate, equatorial bis(pyridyl-NHC) ligand (complex 1, Fig. 1). ${ }^{26}$ Complex 1 catalyzes the oxidation of unreactive alkanes, aromatic hydroxylation, and olefin epoxidation. ${ }^{27-29}$ Beside modification of the equatorial tetradentate ligand it was demonstrated that the electronic structure of $\mathbf{1}$ is significantly influenced by axial ligand exchange. ${ }^{30-32}$ Phosphine- and pyridine-based ligands were used in particular to probe the impact on the redox behavior. ${ }^{30}$

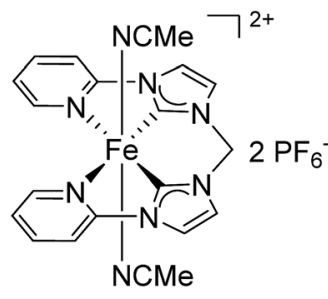

1

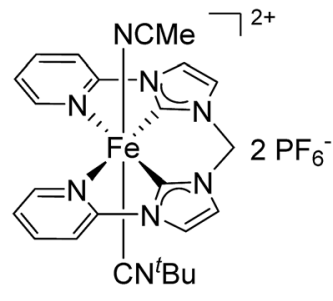

$2 \mathbf{a}$
Fig. $1 \mathrm{Fe}(॥)$ complexes 1 and 2a with a tetradentate, equatorial bis(pyridyl-NHC) ligand. 1 has been applied as a catalyst for the oxidation of unreactive alkanes, aromatic hydroxylation, and olefin epoxidation. ${ }^{27-29} 2 \mathrm{a}$ as catalyst for the oxidation of unreactive alkanes showed an improved performance compared to $1 .^{29}$ 
In order to broaden the scope, tert-butyl isocyanide as easyto-handle ligand with both pronounced $\pi$-acceptor and $\sigma$ donor abilities was successfully used to create an Fe(II) catalyst (2a) with only one accessible coordination site. ${ }^{29}$ As 2 a shows an improved performance as catalyst in the oxidation of unreactive alkanes, it was intended to expand the number of mono(isocyanide)-substituted Fe(II) complexes derived from 1. The use of isocyanides as ligands, being isolobal to carbon monoxide (CO), is well established in coordination chemistry. ${ }^{33-37}$ Modification of the substitution pattern at the isocyanide functionality allows modulation of electronic and steric properties, rendering it a useful alternative to $\mathrm{CO} .^{33,38,39}$

In this article the syntheses, structural, and electronic characterization of $\mathrm{Fe}$ (II) complexes with four isocyanide ligands bearing different substituents are described. The range of mono(isocyanide)-substituted derivatives of $\mathbf{1}$ is extended and also the behavior of $\mathbf{1}$ towards an excess of the respective isocyanide is investigated. Reaction monitoring by NMR spectroscopy is used to identify possible intermediates during the course of reaction. Finally, the impact of isocyanide ligands of the electronic structure of the obtained Fe(II) complexes is studied by cyclic voltammetry and the results are discussed in the context of previously reported findings on the electronic tuning of $\mathrm{Fe}(\mathrm{II})$ complexes. $^{30}$

\section{Results and discussion}

\section{Syntheses of mono(isocyanide)-substituted complexes}

For substitution experiments with different isocyanides the starting complex 1 was dissolved in acetonitrile. Addition of isocyanide at room temperature resulted in a fast change of color from the characteristic orange of $\mathbf{1}$ to bright yellow. Four different isocyanides were used in this study: tert-butyl isocyanide $\left(\mathrm{CN}^{t} \mathrm{Bu}\right)$, cyclohexyl isocyanide (CNCy), benzyl isocyanide (CNBn), and 4-methoxyphenyl isocyanide (CN-p-
PhOMe). Previously, we reported the reaction of 1 with a slight excess (1.0 to 1.5 equiv.) of $\mathrm{CN}^{t} \mathrm{Bu},{ }^{29}$ leading to the formation of mono( $\left(\mathrm{CN}^{t} \mathrm{Bu}\right)$-substituted complex $2 \mathrm{a}$ which was isolated after 30 min reaction time at room temperature (Scheme 1).

The same synthetic procedure was now applied to the reactions of 1 with CNCy, CNBn, and CN-p-PhOMe. In all three cases, the respective mono(isocycanide)-substituted complexes 3a, 4a, and 5a were isolated in yields between 59\% and $94 \%$. In the ${ }^{1} \mathrm{H}$ NMR spectra of $\mathrm{Fe}$ (II) complexes bearing an equatorially coordinating tetradentate NCCN ligand, the chemical shift of the ortho proton signals of the pyridyl moieties are highly sensitive to changes of the electronic structure of the complex, e.g., caused by axial ligand exchange. ${ }^{26,30}$ For the starting material 1 the signal is observed at $9.57 \mathrm{ppm}$, while it is found at $9.26 \mathrm{ppm}$ for $\mathbf{2 a} .{ }^{1} \mathrm{H}$ NMR spectroscopy of $\mathbf{3 a}, \mathbf{4 a}$, and $5 \mathbf{a}$ reveal the signals of the ortho protons at $9.26 \mathrm{ppm}, 9.28 \mathrm{ppm}$, and 9.23 ppm, respectively. These shifts are almost identical for all four mono(isocyanide)-substituted Fe(II) complexes, indicating a negligible influence of the substituents of the isocyanide functional group on the electronic structure of the respective complexes. Only minor changes in the chemical shifts of all other signals of the NCCN ligand are found in the ${ }^{1} \mathrm{H}$ NMR spectra. Characteristic for the monosubstitution pattern, the signal of the $\mathrm{CH}_{2}$ bridge of the NCCN ligand changes from a singlet in case of $\mathbf{1}$ to a doublet of doublets for $\mathbf{2 a - 5 a}$. This is a consequence of broken symmetry in the equatorial plane, as the trans-positioned axial ligands are no longer identical. Additionally, ESI-MS data confirmed the monosubstitution in solution ( $\mathrm{m} / \mathrm{z} 611.47$ (3a), 660.41 (4a), 676.41 (5a)).

Single crystals suitable for X-ray diffraction were obtained for 3a and $\mathbf{4 a}$ by slow diffusion of diethyl ether into a saturated acetonitrile solution of the respective complexes. The molecular structures of the cationic fragments are shown in Fig. 2. The molecular structures of $\mathbf{3 a}$ and $\mathbf{4 a}$ are very similar with the tetradentate NCCN ligand being arranged equatorially.

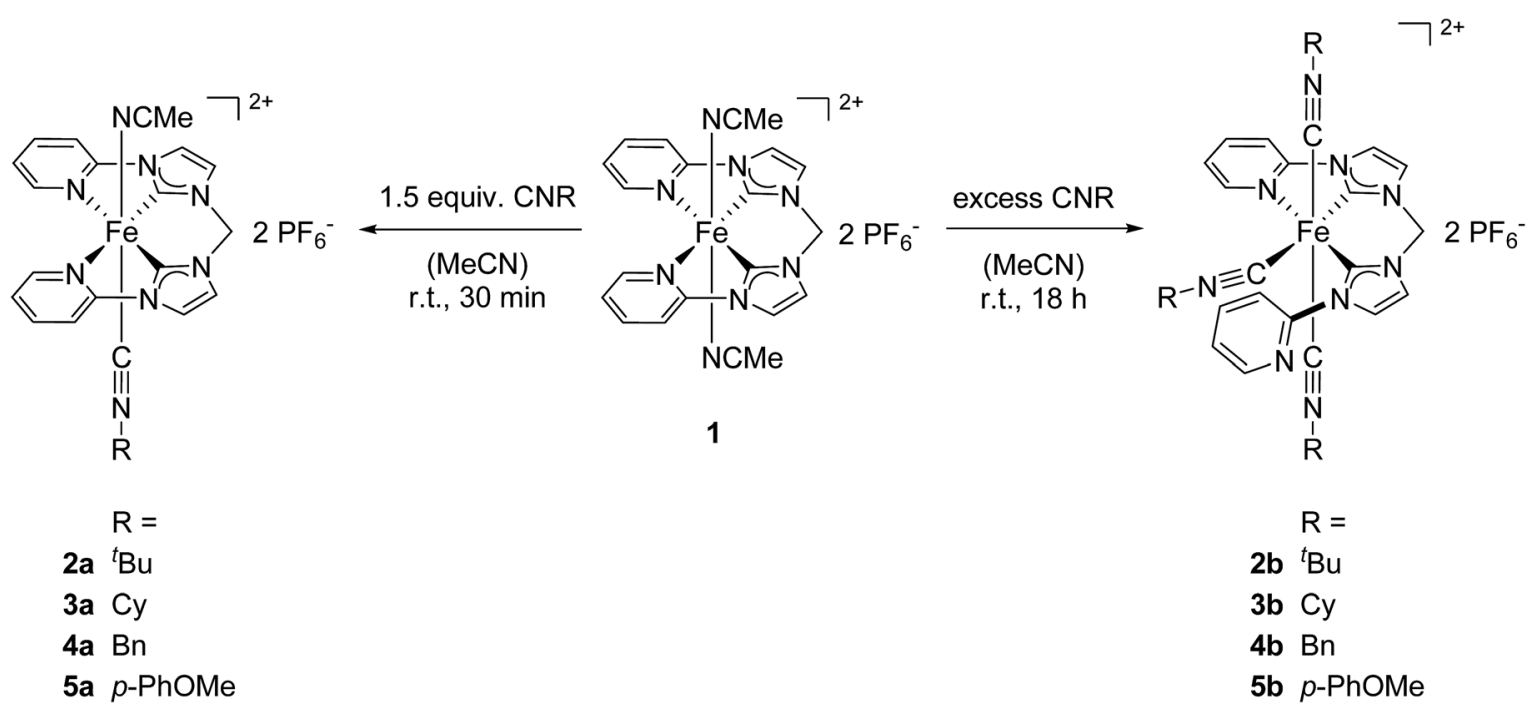

Scheme 1 Syntheses of mono(isocyanide)-substituted complexes $2 a-5 a$ and tri(isocyanide)-substituted complexes $2 b-5 b$ starting from 1 . Complex $2 \mathrm{a}$ had already been reported before by our group. ${ }^{29}{ }^{t} \mathrm{Bu}=$ tert-butyl, $\mathrm{Cy}=$ cyclohexyl, $\mathrm{Bn}=$ benzyl, $p$-PhOMe $=4$-methoxyphenyl. 


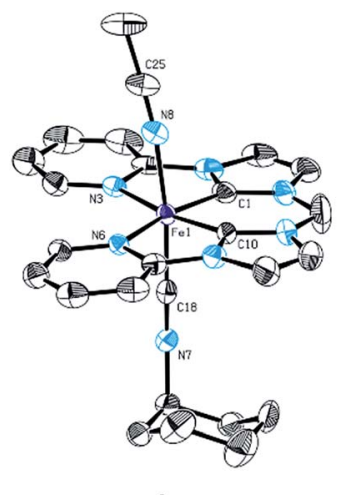

$3 a$

Fig. 2 ORTEP style representation of the cationic fragments of $3 a$ and $4 a$ with ellipsoids shown at a $50 \%$ probability level. Hydrogen atoms and $\mathrm{PF}_{6}{ }^{-}$counter ions are omitted for clarity. Selected bond lengths $\left.[\AA]\right]$ and angles $\left[{ }^{\circ}\right]$ : (3a) Fe1-C1 1.831(4), Fe1-C10 1.836(4), Fe1-N3 2.087(3), Fe1-N6 2.088(3), Fe1-C18 1.847(4), Fe1-N8 1.959(3), C18N7 1.153(4), N3-Fe1-N6 115.03(11), C18-Fe1-N8 172.82(14); (4a) Fe1C1 1.839(3), Fe1-C10 1.834(3), Fe1-N3 2.079(2), Fe1-N6 2.086(2), Fe1-C18 1.852(3), Fe1-N8 1.953(2), C18-N7 1.152(3), N3-Fe1-N6 115.11(8), C18-Fe1-N8 170.56(10).

Compared to both starting material $\mathbf{1}$ and $\operatorname{mono}\left(\mathrm{CN}^{t} \mathrm{Bu}\right)$ substituted complex 2a the distances between the Fe atom and the coordinating atoms in the equatorial plane remain almost unchanged for 3a and 4a. Relevant structural parameters for the coordinated isocyanides such as the Fe-C distances (Fe1-C18: 1.847(4) A for 3a and 1.852(3) A for 4a) and the C-N bond lengths

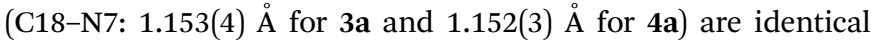
within the error margin for both mono(isocyanide)-substituted complexes. The distance of the acetonitrile ligand trans to the isocyanide is slightly larger for 2a-4a (Fe1-N8: 1.963(4) A for $2 \mathbf{a},{ }^{29} 1.959(3) \AA$ for $3 \mathbf{a}$, and 1.953(2) $\AA$ for $\mathbf{4 a}$ ) compared to $\mathbf{1}$ (1.9151(1) §).

\section{Syntheses of tri(isocyanide)-substituted complexes}

Based on the successful isolation of the monosubstituted Fe(II) complexes the synthesis of disubstituted derivatives with both axial acetonitrile ligands being replaced by isocyanides was targeted. Thus, the amount of isocyanide for the reactions with 1 was increased to 2 equiv. on NMR scale, starting with $\mathrm{CN}^{t} \mathrm{Bu}$. Unexpectedly, ${ }^{1} \mathrm{H}$ NMR spectroscopy revealed a mixture of the monosubstituted complex $\mathbf{2 a}$ and a second compound. Based on the signal pattern this compound could not be described as the expected disubstituted $\mathrm{Fe}(\mathrm{II})$ complex. In order to identify the second species, an excess of $\mathrm{CN}^{t} \mathrm{Bu}$ ( 5 equiv.) was used for the reaction on an NMR scale. The resulting ${ }^{1} \mathrm{H}$ NMR spectrum revealed complete conversion of 1 to the second, unidentified species and the presence of free $\mathrm{CN}^{t} \mathrm{Bu}$ (Fig. 3). An additional increase of the amount of $\mathrm{CN}^{t} \mathrm{Bu}$ to 10 equiv. did not result in any further change of the ${ }^{1} \mathrm{H}$ NMR spectrum.

Based on the splitting pattern of the signals and the integral ratios the novel compound was identified as the $\operatorname{tri}\left(\mathrm{CN}^{t} \mathrm{Bu}\right)$ substituted Fe(II) complex $\mathbf{2 b}$ (see Scheme 1). One of the pyridyl moieties of the former tetradentate NCCN ligand decoordinates the iron atom, and the additionally accessible

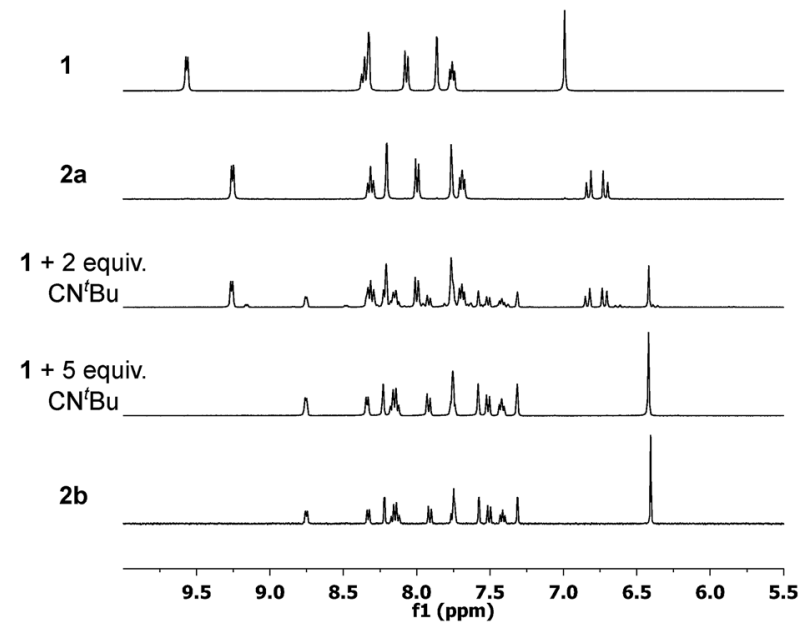

Fig. 3 Selected range (5.5 ppm to $10 \mathrm{ppm}$ ) of ${ }^{1} \mathrm{H}$ NMR spectra of the reaction of 1 with 2 equiv. $\mathrm{CN}^{t} \mathrm{Bu}$ and 5 equiv. $\mathrm{CN}^{t} \mathrm{Bu}$ after 18 hours reaction time. For comparison, ${ }^{1} \mathrm{H}$ NMR spectra of isolated $1,2 \mathrm{a}$, and $2 \mathrm{~b}$ are shown.

coordination site is occupied by $\mathrm{CN}^{t} \mathrm{Bu}$ trans to an NHC moiety. Also, both axial acetonitrile ligands have been replaced by $\mathrm{CN}^{t} \mathrm{Bu}$. As a consequence of the broken symmetry a full set of signals, with no symmetry equivalent protons, is observed for the NCCN ligand in the ${ }^{1} \mathrm{H}$ NMR spectrum of $\mathbf{2 b}$. This is quite different from the situation observed for $\mathbf{1}$ and 2a-5a. With chemical shifts of $8.75 \mathrm{ppm}$ and $8.33 \mathrm{ppm}$ both signals of the ortho protons of the pyridyl moieties are shifted upfield compared to $9.26 \mathrm{ppm}$ for $2 \mathrm{a}$ and $9.57 \mathrm{ppm}$ for $1 .^{26,30}$ An additional confirmation of the trisubstitution pattern is given by ESI-MS data, showing a distinct signal at $m / z 751.82$.

The tri(isocyanide) substitution was successfully extended to the isocyanides CNCy, CNBn, and $\mathrm{CN}-p$-PhOMe to yield complexes $\mathbf{3 b}, \mathbf{4 b}$, and $\mathbf{5 b}$, respectively. In all cases, an excess of the respective isocyanide in the presence of $\mathbf{1}$ leads to the formation of the tri(isocyanide)-substituted products. The course of the reaction is very similar to the formation of $\mathbf{2 b}$ from 1, with an excess of isocyanide being required for selective formation of $\mathbf{2 b} \mathbf{b} \mathbf{5} \mathbf{b}$. Addition of only 2 equiv. isocyanide yields a mixture of the respective mono- and tri-substituted complexes. The presence of three isocyanides coordinating to Fe is confirmed by ESI-MS in solution $(\mathrm{m} / \mathrm{z} 829.94(3 \mathbf{b}), 354.37$ (4b, dicationic fragment $z=2$ ), 901.65 (5b)). ${ }^{1} \mathrm{H}$ NMR spectroscopy reveals signals in a very similar pattern to $\mathbf{2 b}$ for all three complexes with the signal of the ortho protons of the pyridyl moieties showing chemical shifts of $8.77 \mathrm{ppm}$ and 8.32 ppm for $3 \mathbf{b}, 8.56 \mathrm{ppm}$ and $8.20 \mathrm{ppm}$ for $\mathbf{4 b}$, and $8.53 \mathrm{ppm}$ and $8.44 \mathrm{ppm}$ for $5 \mathbf{b}$ (compare $2 \mathbf{b}: 8.75 \mathrm{ppm}$ and $8.33 \mathrm{ppm}$ ). In addition to characterization in solution, single crystals suitable for X-ray diffraction were obtained for $\mathbf{2 b}, \mathbf{3 b}$, and $\mathbf{5 b}$ (Fig. 4 ).

From the molecular structures shown in Fig. 4 it is evident that indeed one of the pyridyl moieties is no longer coordinating to the Fe atom as the ${ }^{1} \mathrm{H}$ NMR data suggest. The former tetradentate NCCN ligands coordinate meridional in a tridentate fashion and three isocyanides occupy the remaining coordination sites, completing the octahedral geometry of the 


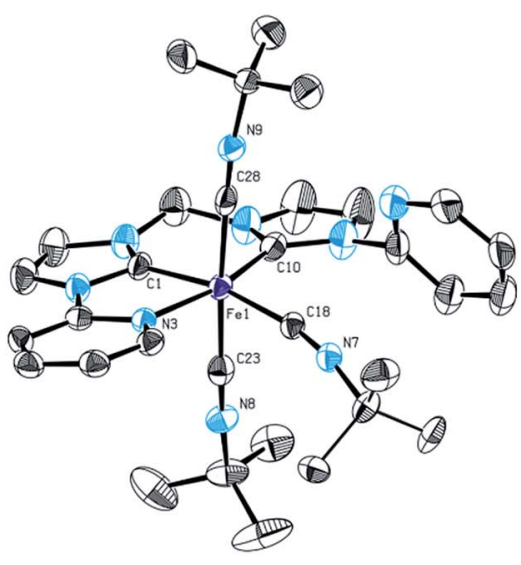

2b

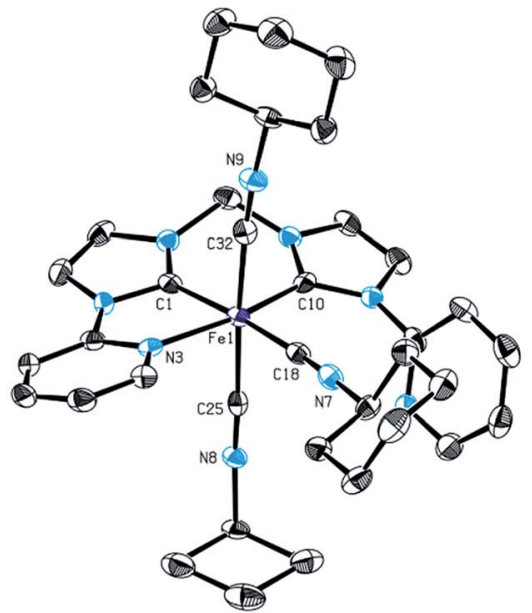

3b

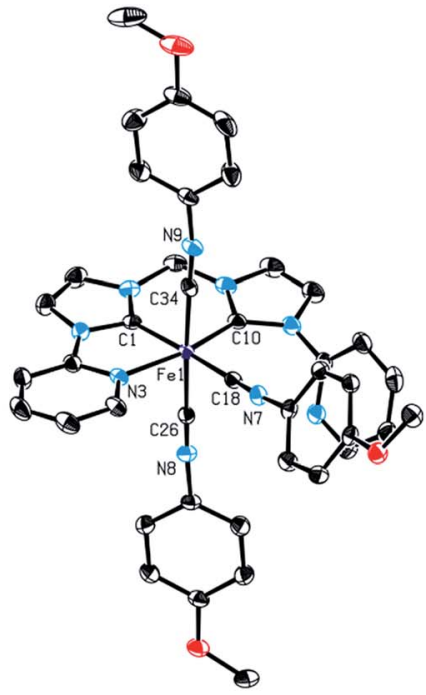

$5 b$

Fig. 4 ORTEP style representation of the cationic fragments of $2 b, 3 b$, and $5 b$ with ellipsoids shown at a $50 \%$ probability level. Hydrogen atoms and $\mathrm{PF}_{6}{ }^{-}$counter ions are omitted for clarity. Selected bond lengths [Å] and angles [ $\left.{ }^{\circ}\right]$ : (2b) Fe1-C1 1.885(4), Fe1-C10 1.952(4), Fe1-N3 2.069(3), Fe1-C18 1.904(4), Fe1-C23 1.881(4), Fe1-C28 1.892(4), C18-N7 1.149(5), C23-N8 1.152(5), C28-N9 1.152(5), N3-Fe1-C18 92.69(14), C10-Fe1C18 101.41(16), C23-Fe1-C28 175.25(16); (3b) Fe1-C1 1.869(4), Fe1-C10 1.951(4), Fe1-N3 2.060(3), Fe1-C18 1.890(5), Fe1-C25 1.892(4), Fe1C32 1.892(5), C18-N7 1.159(5), C25-N8 1.151(5), C32-N9 1.144(5), N3-Fe1-C18 94.60(15), C10-Fe1-C18 100.30(17), C25-Fe1-C32 176.06(17); (5b) Fe1-C1 1.8825(19), Fe1-C10 1.9460(19), Fe1-N3 2.0594(16), Fe1-C18 1.881(2), Fe1-C26 1.893(2), Fe1-C34 1.876(2), C18-N7 1.158(3), C26N8 1.154(3), C34-N9 1.161(3), N3-Fe1-C18 93.87(7), C10-Fe1-C18 100.23(8), C26-Fe1-C34 176.89(8).

$\mathrm{Fe}(\mathrm{II})$ complexes. Due to the induced asymmetry, the $\mathrm{Fe}-\mathrm{C}_{\mathrm{NHC}}$ bond lengths differ between the two NHC units. Within the meridional tridentate NCC ligands, the central NHC units show

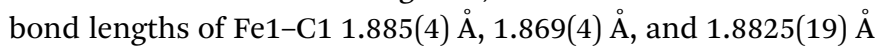
for $\mathbf{2 b}, \mathbf{3 b}$, and $\mathbf{5 b}$, respectively. Compared to that, the Fe1-C10 bonds of the other NHC units are slightly longer with values of

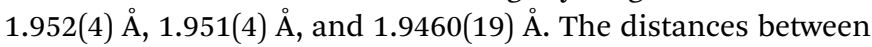
iron and the isocyanide ligands trans to the NHC moiety are

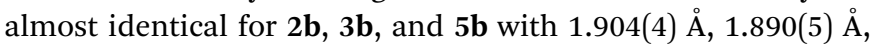
and $1.881(2) \AA$, respectively, and with a range of $1.876(2) \AA$ to 1.892(5) $\AA$ for the two isocyanides trans to each other. In all cases the isocyanide $\mathrm{C}-\mathrm{N}$ bond lengths are in the typical range of isocyanide-coordinated Fe-NHC complexes with values in the range of 1.144(5) ̊̊ to 1.161(3) $\AA^{.40}$ Interestingly, no well-defined difference is observed between the isocyanide trans to the NHC unit and the isocyanides that are positioned trans to each other.

\section{Time-dependent analysis of ligand exchange reaction}

During the formation of the tri(isocyanide)-substituted $\mathrm{Fe}$ (II) complexes it is likely that an intermediate species bearing two isocyanide ligands is formed. As characteristic signals of $2 \mathbf{a}$ and 2b in ${ }^{1} \mathrm{H}$ NMR do not overlap (see Fig. 3), the reaction of 1 with 5 equiv. $\mathrm{CN}^{t} \mathrm{Bu}$ was monitored over time by ${ }^{1} \mathrm{H}$ NMR spectroscopy. With the first data point being collected after 3 minutes, the initial reaction step (formation of $\mathbf{2 a}$ from $\mathbf{1}$ ) proceeded too fast to be monitored at room temperature. Thus, the spectra were recorded at $10{ }^{\circ} \mathrm{C}$. Based on the ${ }^{1} \mathrm{H}$ NMR spectra, four different species were observed during the reaction (Fig. 5).

The amount of starting material 1 (purple triangles) quickly decays after addition of $\mathrm{CN}^{t} \mathrm{Bu}$. At the first data point after 3 minutes only $14 \%$ of 1 are left in the reaction mixture, and after 9 min complex 1 has been converted completely to its isocyanide-substituted derivatives. As initial intermediate mono( $\left.\mathrm{CN}^{t} \mathrm{Bu}\right)$-substituted complex $\mathbf{2 a}$ is formed (blue $\times$ ) with a peak accumulation of $84 \%$ after $7 \mathrm{~min}$. Subsequently, 2 a further reacts to form its higher-substituted derivatives and after $80 \mathrm{~min} 2 \mathbf{a}$ is no longer detected in the reaction mixture. Most interestingly, at the first data point after $3 \mathrm{~min}$ a third

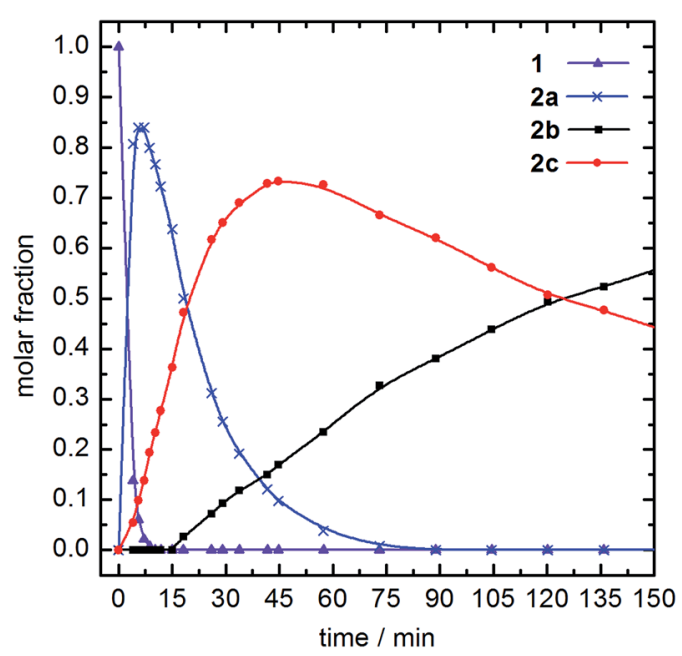

Fig. 5 Time-dependent analysis of the reaction of 1 (purple triangles) with 5 equiv. $\mathrm{CN}^{t} \mathrm{Bu}$ at $10{ }^{\circ} \mathrm{C}$, monitored by ${ }^{1} \mathrm{H}$ NMR spectroscopy. Initial formation of 2 a (blue cross) is observed, followed by the formation of an additional, intermediate compound (red circles) and $2 b$ (black squares). 


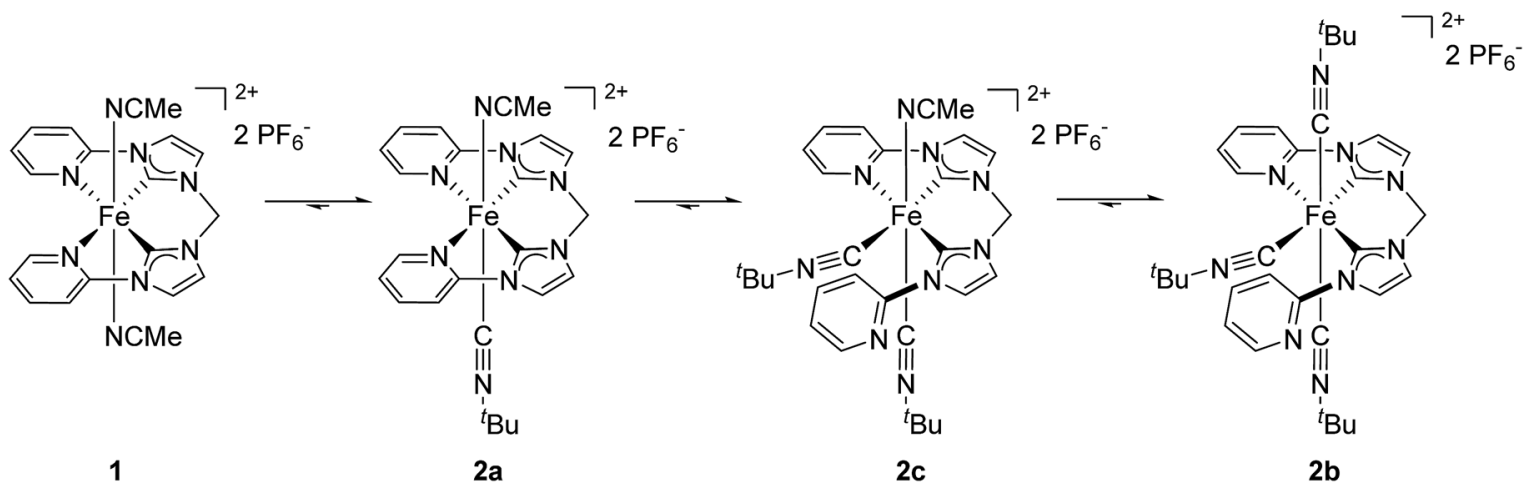

Scheme 2 Suggested pathway for the reaction of 1 with excess of $C N^{t} B u$ to form tri(CN $\left.{ }^{t} B u\right)$-substituted complex $2 b$.

species beside $\mathbf{1}$ and $\mathbf{2 a}$ is identified (red circles) which accumulates to $73 \%$ after $40 \mathrm{~min}$ before its amount starts to decrease again. Based on the signal pattern in ${ }^{1} \mathrm{H}$ NMR, this intermediate is not identical to $\mathbf{1}, \mathbf{2 a}$, or the $\operatorname{tri}\left(\mathrm{CN}^{t} \mathbf{B u}\right)$ substituted $\mathbf{2 b}$, which starts to form after 15 min (black squares). The integral ratio and the splitting pattern of the intermediate species suggest a $\mathrm{di}\left(\mathrm{CN}^{t} \mathrm{Bu}\right)$-substituted complex 2c. Two singlet signals at $1.09 \mathrm{ppm}$ and $1.42 \mathrm{ppm}$ with each having an integral of 9 are assigned to the two tert-butyl groups of the isocyanide ligands while the signal of the $\mathrm{CH}_{2}$ bridge is split up to a doublet of doublets at $6.49 \mathrm{ppm}$ with an overall integral of 2. As a full set of signals is observed for the remaining protons of the tetradentate ligand, a highly asymmetric structure for $\mathbf{2 c}$ is likely (Scheme 2). The observed asymmetry can only be achieved by a cis arrangement of the $\mathrm{CN}^{t} \mathrm{Bu}$ ligands, as a simple exchange of the trans labile acetonitrile of 2a would result in a highly symmetric structure with an ${ }^{1} \mathrm{H}$ NMR signal pattern similar to $\mathbf{1 .}^{\mathbf{3 0}}$ Hence, the meridional coordination pattern shown in Scheme 2 is indicated by the spectroscopic data for $\mathbf{2 c}$ as well. Based on time-dependent ratios of the Fe(II) complexes as shown in Fig. 5 each subsequent substitution by one additional $\mathrm{CN}^{t} \mathrm{Bu}$ starting from 1 proceeds slower. In the presence of an excess of isocyanide complex $\mathbf{1}$ is bound to form $\mathbf{2 b}$, which is the thermodynamically most favored compound in the substitution equilibrium. The thermodynamic stability of $\mathbf{2} \mathbf{b}$ and all other tri-substituted complexes $\mathbf{3 b} \mathbf{b}-\mathbf{5 b}$ is also evident from ${ }^{1} \mathrm{H}$ NMR data in acetonitrile, as the respective spectra do not change after storing the samples for several days under air. No exchange of the coordinating isocyanides by acetonitrile is observed, which stands in contrast to the observations reported for phosphine-based ligands. ${ }^{30}$

\section{Electrochemical investigations}

Previous studies have revealed a significant influence of the substitution of the labile acetonitrile ligands of $\mathbf{1}$ on the electronic structure of Fe(II) complexes. ${ }^{30}$ This was investigated both theoretically by DFT calculations and experimentally by determination of the half-cell potentials with cyclic voltammetry. While the half-cell potential of 1 was determined to be $423 \mathrm{mV}$ (versus $\mathrm{Fc} / \mathrm{Fc}^{+}$), an exchange of only one acetonitrile ligand with
$\mathrm{PMe}_{3}$ reduced the half-cell potential to $325 \mathrm{mV}$. For the mono(isocyanide)-substituted complexes $\mathbf{2 a - 5 a}$ an increase in half-cell potential is expected compared to $\mathbf{1}$, as isocyanides are $\pi$-acceptor ligands in addition to their $\sigma$-donor properties. Coordination of a $\pi$-acceptor ligand should result in a decreased electron density at the iron atom, resulting in a higher potential required for the oxidation of $\mathrm{Fe}(\mathrm{II})$ to $\mathrm{Fe}(\mathrm{III})$. This should also hold true for the tri(isocyanide)-substituted complexes $\mathbf{2 b} \mathbf{b}-\mathbf{5 b}$. In order to investigate the impact of the isocyanide ligands on the redox behavior of the respective complexes, all compounds 2-5 were subjected to cyclic voltammetry experiments and the respective data is shown in Fig. 6.

For all mono(isocyanide)-substituted complexes 2a-5a a fully reversible oxidation, assigned to the $\mathrm{Fe}(\mathrm{II} / \mathrm{Fe}(\mathrm{III})$ redox couple, is observed. The half-cell potentials versus $\mathrm{Fc} / \mathrm{Fc}^{+}$are $539 \mathrm{mV}$ for 2a, $540 \mathrm{mV}$ for $3 \mathrm{a}, 557 \mathrm{mV}$ for $\mathbf{4 a}$, and $573 \mathrm{mV}$ for $\mathbf{5 a}$. As expected, in all cases the required potential for the oxidation of
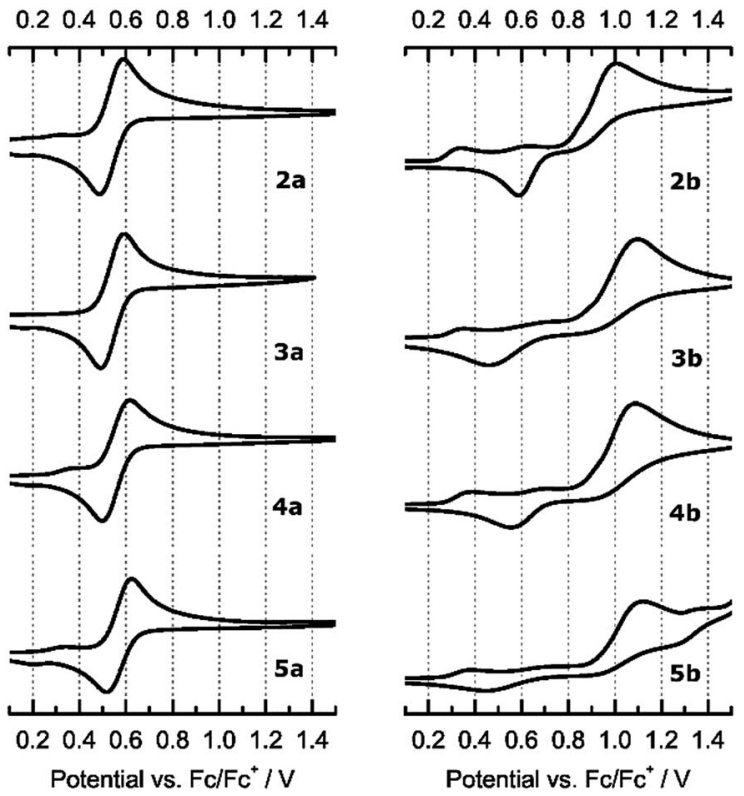

Fig. 6 Cyclic voltammograms of mono(isocyanide)-(2a-5a, left) and tri(isocyanide)-substituted Fe(॥) complexes ( $2 b-5 b$, right). 
$\mathrm{Fe}(\mathrm{II})$ is significantly higher (116 $\mathrm{mV}$ to $150 \mathrm{mV}$ ) than observed for 1 and also for its mono( $\left(\mathrm{PMe}_{3}\right)$-substituted derivative reported earlier. Within the series of $\mathbf{2 a - 5 a}$, the variation of the substituents on the isocyanide functionalities has a small influence on the half-cell potentials. Bearing alkyl substituents, complexes $2 \mathbf{a}\left({ }^{t} \mathrm{Bu}\right)$ and $\mathbf{3 a}(\mathrm{Cy})$ show identical half-cell potentials, while the benzyl substituent in case of $4 a$ leads to a slightly increased potential. For 5a this effect is more pronounced as the aryl substituent ( $p$-PhOMe) influences the isocyanide functionality to a greater extent due to $\pi$-conjugation. Cyclic voltammetry experiments of tri(isocyanide)-substituted complexes $\mathbf{2 b}$ $\mathbf{5 b}$, however, lead to different results. In all cases, the oxidation is no longer reversible and requires a significantly higher potential than $\mathbf{2 a - 5 a}$. The peak current for the oxidation from $\mathrm{Fe}(\mathrm{II})$ to $\mathrm{Fe}(\mathrm{III})$ was found at $994 \mathrm{mV}$ for $\mathbf{2 b}, 1091 \mathrm{mV}$ for $\mathbf{3 b}, 1076$ $\mathrm{mV}$ for $\mathbf{4 b}$, and $1092 \mathrm{mV}$ for $\mathbf{5 b}$ (all versus $\mathrm{Fc} / \mathrm{Fc}^{+}$). As $\mathbf{2 b}-\mathbf{5 b}$ are bearing three isocyanide ligands, the higher oxidation potentials can be explained by the accumulated electron-withdrawing ability of the $\pi$-acceptor ligands, leading to a significantly reduced electron density at the iron atoms. A possible explanation for the irreversibility is the instability of the oxidized Fe complexes in the oxidation state + III, induced by the presence of three $\pi$-acceptor ligands.

It is likely that after oxidation to $\mathrm{Fe}(\mathrm{III})$, the remaining electron density is no longer sufficient to maintain the given coordination environment and therefore one of the isocyanide ligands is removed from the coordination sphere. Consequently, the loss of one $\pi$-acceptor ligand most likely changes the respective reduction potential and the overall redox process is no longer reversible. Indeed, an independent, irreversible reduction wave was observed for $2 \mathbf{b}(592 \mathrm{mV}), 3 \mathbf{b}(487 \mathrm{mV})$, and $\mathbf{4 b}(562 \mathrm{mV})$. In case of $\mathbf{5 b}$ this reduction wave is indicated only vaguely at $448 \mathrm{mV}$. Based on the NMR data for the reaction of 1 with excess $\mathrm{CN}^{t} \mathrm{Bu}$ to form $\mathbf{2 b}$ (see above) and the irreversibility of the electrochemical oxidation of $\mathbf{2 b} \mathbf{b} \mathbf{5} \mathbf{b}$ from $\mathrm{Fe}(\mathrm{II})$ to $\mathrm{Fe}(\mathrm{III})$, these reduction waves are understood to have their origin in the respective di(isocyanide)-substituted intermediates.

\section{Experimental}

\section{General remarks}

All chemicals were purchased from commercial suppliers and used without further purification. Complexes $\mathbf{1}$ and 2a were synthesized according to the literature. ${ }^{26,29,41}$ Liquid NMR spectra were recorded on a Bruker Avance DPX 400 and a Bruker Ultrashield 500 Plus with cryo unit. Chemical shifts are given in parts per million (ppm) and the spectra were referenced by using the residual solvent shifts as internal standards (MeCN$d_{3},{ }^{1} \mathrm{H}$ NMR $\delta 1.94,{ }^{13} \mathrm{C}$ NMR $\delta 1.32$ ). A Thermo Scientific LCQ/ Fleet spectrometer by Thermo Fisher Scientific was used to collect MS-ESI data and elemental analyses were obtained from the microanalytical laboratory of TUM.

\section{Single crystal X-ray diffraction}

Single crystals of $\mathbf{3 a}, \mathbf{4 a}, \mathbf{2} \mathbf{b}$, and $\mathbf{3 b}$ suitable for X-ray diffraction were obtained by slow diffusion of diethyl ether into an acetonitrile solution of respective compounds. In case of $\mathbf{5 b}$ slow diffusion of diethyl ether into an acetone solution of $\mathbf{5 b}$ yielded single crystals. 3a: yellow, monoclinic crystal system, space group $P 2_{1} / c$ (no. 14), $a=19.1865(9) \AA, b=10.7359(4) \AA, c$ $=15.8045(7) \AA, \beta=40.406(2)^{\circ}, V=3211.7(2) \AA^{3}$. 4a: yellow, triclinic crystal system, space group $P \overline{1}$ (no. 2$), a=8.0698(5) \AA$, $b=10.1378(7) \AA, c=19.5360(13) \AA, \alpha=98.549(3)^{\circ}, \beta=$ 101.122(3) $)^{\circ} \gamma=100.397(3)^{\circ}, V=1514.35(17) \AA^{3}$. 2b: yellow, triclinic crystal system, space group $P \overline{1}$ (no. 2), $a=12.0501(4) \AA$, $b=17.2210(5) \AA, c=20.7696(6) \AA, \alpha=69.987(2)^{\circ}, \beta=$ $86.127(2)^{\circ}, \gamma=85.440(2)^{\circ}, V=4033.2(2) \AA^{3}$. 3b: yellow, monoclinic crystal system, space group $P 2_{1} / c$ (no. 14), $a=19.9697(7)$ $\AA, b=11.5746(3) \AA, c=18.9375(7) \AA, \beta=100.129(2)^{\circ}, V=$ 4309.0(2) $\AA^{3}$. 5b: yellow, monoclinic crystal system, space group $P 2{ }_{1} / c$ (no. 14) $a=8.08910(10) \AA, b=21.8620(3) \AA, c=24.9410(3)$ $\AA, \beta=96.7210(10)^{\circ}, V=4380.35(10) \AA^{3}$. Crystallographic data for structures $3 \mathbf{a}, \mathbf{4 a}, \mathbf{2 b}, \mathbf{3 b}$, and $\mathbf{5 b}$ have been deposited with the Cambridge Crystallographic Data Centre (CCDC 1422720$1422724 \dagger)$.

\section{Cyclic voltammetry}

A PalmSens EmStat ${ }^{3+}$ potentiostat was used together with the PSTrace4 software for cyclic voltammetry measurements. A platinum wire was chosen as counter electrode, together with glassy carbon as working electrode and $\mathrm{Ag} / \mathrm{AgNO}_{3}(0.01 \mathrm{M}$ in acetonitrile with $0.1 \mathrm{M}$ tetrabutylammonium hexafluorophosphate) as reference electrode. For all measurements, 3.0 $\mathrm{mg}$ of the respective compound was dissolved in $1.0 \mathrm{~mL}$ of acetonitrile under inert conditions, containing $0.1 \mathrm{mmol}$ tetrabutylammonium hexafluorophosphate. The potential was scanned with $100 \mathrm{mV} \mathrm{s}{ }^{-1}$ versus $\mathrm{Ag} / \mathrm{AgNO}_{3}$ and the obtained values were referenced versus the $\mathrm{Fc} / \mathrm{Fc}^{+}$redox couple as internal standard (0.48 V versus SCE). ${ }^{42}$

\section{Syntheses of complexes}

General procedure for the syntheses of mono(isocyanide)substituted complexes. In a round bottom flask, complex $\mathbf{1}$ is dissolved in acetonitrile and 1.5 equivalents of isocyanide are added while stirring. Within minutes, the orange solution changes its color to yellow and after 30 minutes of stirring at room temperature diethyl ether is added. The precipitate is collected by filtration and washed three times with diethyl ether. After drying under vacuum the desired product is obtained as air-stable, yellow powder.

3a-[Fe(NCCN)(MeCN)(CNCy)](PF $)_{2} .64 .5 \mathrm{mg}, 59 \%$ yield. ${ }^{1} \mathrm{H}$ NMR (400.13 MHz, MeCN- $d_{3}$ ): $\delta 9.27$ (d, $J=5.4 \mathrm{~Hz}, 2 \mathrm{H}, o-H_{\mathrm{py}}$ ), $8.33-8.29\left(\mathrm{~m}, 2 \mathrm{H}, H_{\mathrm{py}}\right), 8.21\left(\mathrm{~d}, J=2.3 \mathrm{~Hz}, 2 \mathrm{H}, H_{\mathrm{NHC}}\right), 8.00(\mathrm{~d}, J=$ $\left.8.3 \mathrm{~Hz}, 2 \mathrm{H}, H_{\mathrm{py}}\right), 7.77\left(\mathrm{~d}, J=2.3 \mathrm{~Hz}, 2 \mathrm{H}, H_{\mathrm{NHC}}\right), 7.71-7.67(\mathrm{~m}$, $2 \mathrm{H}, H_{\text {py }}$ ), 6.77 (dd, $J=12.4 \mathrm{~Hz}$ and $53.6 \mathrm{~Hz}, 2 \mathrm{H}, \mathrm{CH}_{2}$ ), 3.37 (br, $\left.1 \mathrm{H}, \mathrm{CH}_{\mathrm{Cy}}\right), 1.27-1.22\left(\mathrm{~m}, 2 \mathrm{H}, \mathrm{CH}_{2, \mathrm{Cy}}\right), 1.11-1.08$ (m, 6H, $\mathrm{CH}_{2, \mathrm{Cy}}$ ), 0.72 (br, 2H, CH$H_{2, \mathrm{Cy}}$ ). ${ }^{13} \mathrm{C}\left\{{ }^{1} \mathrm{H}\right\}$ NMR (125.83 MHz, MeCN- $d_{3}$ ): $\delta$ 209.2, 154.4, 153.5, 142.3, 125.7, 124.3, 119.8, 113.4, 64.7, 55.6, 32.0, 25.1, 21.8. IR $\left(\mathrm{cm}^{-1}\right): \nu(\mathrm{C} \equiv \mathrm{N})$ 2157. MS-ESI $(\mathrm{m} / \mathrm{z}):[3 \mathrm{a}-$ $\left.2 \mathrm{PF}_{6}\right]^{2+}$ calcd, 233.58; found, 233.44. Anal. calcd for $\mathrm{C}_{26} \mathrm{H}_{28} \mathrm{~F}_{12}$ $\mathrm{FeN}_{8} \mathrm{P}_{2}$ : C, 39.12; H, 3.54; N, 14.04. Found: C, 39.01; H, 3.34; N, 13.69 . 
4a-[Fe(NCCN)(MeCN)(CNBn)](PF $)_{2}$. $517 \mathrm{mg}, 94 \%$ yield. ${ }^{1} \mathrm{H}$ NMR (400.13 MHz, MeCN- $\left.d_{3}\right): \delta 9.24\left(\mathrm{~d}, J=5.2 \mathrm{~Hz}, 2 \mathrm{H}, o-H_{\mathrm{py}}\right)$, $8.31\left(\mathrm{t}, J=7.8 \mathrm{~Hz}, 2 \mathrm{H}, H_{\mathrm{py}}\right), 8.19\left(\mathrm{~d}, J=2.1 \mathrm{~Hz}, 2 \mathrm{H}, H_{\mathrm{NHC}}\right), 7.98$ $\left(\mathrm{d}, J=8.3 \mathrm{~Hz}, 2 \mathrm{H}, H_{\mathrm{py}}\right), 7.75\left(\mathrm{~d}, J=2.1 \mathrm{~Hz}, 2 \mathrm{H}, H_{\mathrm{NHC}}\right), 7.69-7.66$ (m, 2H, $\left.H_{\mathrm{py}}\right), 7.24-7.16\left(\mathrm{~m}, 3 \mathrm{H}, H_{\mathrm{Bn}}\right), 6.82(\mathrm{~d}, J=12.4 \mathrm{~Hz}, 1 \mathrm{H}$, $\left.\mathrm{CH}_{2}\right)$, 6.65-6.60 (m, $H_{\mathrm{Bn}}$ and $\left.\mathrm{CH}_{2}\right), 4.30\left(\mathrm{~s}, 2 \mathrm{H}, \mathrm{CH}_{2, \mathrm{Bn}}\right) .{ }^{13} \mathrm{C}\left\{{ }^{1} \mathrm{H}\right\}$ NMR (125.83 MHz, MeCN- $\left.d_{3}\right): \delta 208.6,154.4,153.5,142.3,134.5$, 129.8, 129.1, 126.8, 125.7, 124.3, 119.8, 113.3, 64.8, 49.2. IR $\left(\mathrm{cm}^{-1}\right): \nu(\mathrm{C} \equiv \mathrm{N})$ 2173. MS-ESI $(\mathrm{m} / \mathrm{z}):\left[4 \mathrm{a}-\mathrm{PF}_{6}\right]^{+}$calcd, 661.11; found, 660.41; [4a-2PF $]^{+}$calcd, 258.08; found, 257.92. Anal. calcd for $\mathrm{C}_{27} \mathrm{H}_{24} \mathrm{~F}_{12} \mathrm{FeN}_{8} \mathrm{P}_{2}$ : C, 40.22; H, 3.00; N, 13.90. Found: C, 39.80 ; H, 3.30; N, 13.81 .

5a-[Fe(NCCN)(MeCN)(CN-p-PhOMe)](PF $)_{2}$. $141 \mathrm{mg}, \quad 83 \%$ yield. ${ }^{1} \mathrm{H}$ NMR $\left(400.13 \mathrm{MHz}, \mathrm{MeCN}-d_{3}\right): \delta 9.28(\mathrm{~d}, J=5.0 \mathrm{~Hz}, 2 \mathrm{H}$, $\left.o-H_{\mathrm{py}}\right), 8.32\left(\mathrm{t}, J=7.8 \mathrm{~Hz}, 2 \mathrm{H}, H_{\mathrm{py}}\right), 8.22\left(\mathrm{~d}, J=1.6 \mathrm{~Hz}, 2 \mathrm{H}, H_{\mathrm{NHC}}\right)$, $8.01\left(\mathrm{~d}, J=8.3 \mathrm{~Hz}, 2 \mathrm{H}, H_{\mathrm{py}}\right), 7.77$ (d, $\left.J=1.6 \mathrm{~Hz}, 2 \mathrm{H}, H_{\mathrm{NHC}}\right), 7.71-$ $7.68\left(\mathrm{~m}, 2 \mathrm{H}, H_{\mathrm{py}}\right), 6.86-6.69\left(\mathrm{~m}, 6 \mathrm{H}, H_{\mathrm{Ph}}\right.$ and $\left.\mathrm{CH}_{2}\right), 3.67(\mathrm{~s}, 3 \mathrm{H}$, $\left.\mathrm{OCH}_{3}\right) .{ }^{13} \mathrm{C}\left\{{ }^{1} \mathrm{H}\right\}$ NMR $\left(125.83 \mathrm{MHz}, \mathrm{MeCN}-d_{3}\right): \delta 207.1,160.5$, 154.4, 513.5, 142.3, 128.1, 125.7, 124.3, 119.9, 115.3, 113.5, 64.8, 56.3. IR $\left(\mathrm{cm}^{-1}\right): \nu(\mathrm{C} \equiv \mathrm{N})$ 2122. MS-ESI $(\mathrm{m} / \mathrm{z}):\left[5 \mathbf{a}-\mathrm{PF}_{6}\right]^{+}$calcd, 677.11; found, 676.41; [5a-MeCN-PF $]^{+}$calcd, 636.08; found, 635.43 .

General procedure for the syntheses of tri(isocyanide)substituted complexes. In a round bottom flask, complex 1 is dissolved in acetonitrile and 5 equivalents of isocyanide are added under stirring. The orange solution is stirred at room temperature for 18 hours, resulting in a color change from orange to yellow. Diethyl ether is added, the precipitate is collected by filtration and washed three times with diethyl ether. After drying under vacuum the desired product is obtained as air-stable, yellow powder.

2b-[Fe(NCC)(CN $\left.\left.{ }^{t} \mathbf{B u}\right)_{3}\right]\left(\mathbf{P F}_{6}\right)_{2} \cdot 65.8 \mathrm{mg}, 54 \%$ yield. ${ }^{1} \mathrm{H}$ NMR $\left(400.13 \mathrm{MHz}, \mathrm{MeCN}-d_{3}\right): \delta 8.75\left(\mathrm{~d}, J=5.9 \mathrm{~Hz}, 1 \mathrm{H}, o-H_{\mathrm{py}}\right), 8.33(\mathrm{~d}, J$ $\left.=5.8 \mathrm{~Hz}, 1 \mathrm{H}, o-H_{\mathrm{py}}\right), 8.22\left(\mathrm{~d}, J=2.2 \mathrm{~Hz}, 1 \mathrm{H}, H_{\mathrm{NHC}}\right), 8.18-8.12(\mathrm{~m}$, $\left.2 \mathrm{H}, H_{\mathrm{py}}\right), 7.91\left(\mathrm{~d}, J=8.2 \mathrm{~Hz}, 1 \mathrm{H}, H_{\mathrm{py}}\right), 7.77-7.74\left(\mathrm{~m}, 2 \mathrm{H}, H_{\mathrm{py}}\right.$ and $\left.H_{\mathrm{NHC}}\right), 7.58\left(\mathrm{~d}, J=2.1 \mathrm{~Hz}, 1 \mathrm{H}, H_{\mathrm{NHC}}\right), 7.51\left(\mathrm{~d}, J=8.0 \mathrm{~Hz}, 1 \mathrm{H}, H_{\mathrm{py}}\right)$, $7.43-7.40\left(\mathrm{~m}, 1 \mathrm{H}, H_{\mathrm{py}}\right), 7.31\left(\mathrm{~d}, J=2.1 \mathrm{~Hz}, 1 \mathrm{H}, H_{\mathrm{NHC}}\right), 6.41(\mathrm{~s}, 2 \mathrm{H}$, $\left.\mathrm{CH}_{2}\right), 1.39\left(\mathrm{~s}, 9 \mathrm{H}, \mathrm{C}\left(\mathrm{CH}_{3}\right)_{3}\right), 1.18\left(\mathrm{~s}, 18 \mathrm{H}, \mathrm{C}\left(\mathrm{CH}_{3}\right)_{3}\right) .{ }^{13} \mathrm{C}\left\{{ }^{1} \mathrm{H}\right\} \mathrm{NMR}$ (125.83 MHz, MeCN- $d_{3}$ ): $\delta 201.7,181.9,153.6,153.4,153.2,150.7$, 141.8, 140.7, 126.9, 126.7, 125.2, 124.5, 124.0, 123.7, 119.9, 113.4, 63.7, 59.7, 59.4, 30.8, 30.2. IR $\left(\mathrm{cm}^{-1}\right): \nu(\mathrm{C} \equiv \mathrm{N}) 2150$. MS-ESI $(\mathrm{m} / \mathrm{z})$ : [2b-PF $]^{+}$calcd, 752.25; found, 751.82.

3b- $\left[\mathbf{F e}(\mathbf{N C C})(\mathbf{C N C y})_{3}\right]\left(\mathbf{P F}_{\mathbf{6}}\right)_{2} .76 .2 \mathrm{mg}, \quad 57 \%$ yield. ${ }^{1} \mathrm{H}$ NMR $\left(400.13 \mathrm{MHz}, \mathrm{MeCN}-d_{3}\right): \delta 8.77\left(\mathrm{~d}, J=4.7 \mathrm{~Hz}, 1 \mathrm{H}, o-H_{\mathrm{py}}\right), 8.31(\mathrm{~d}, J$ $\left.=5.6 \mathrm{~Hz}, 1 \mathrm{H}, H_{\mathrm{py}}\right), 8.22\left(\mathrm{~d}, J=2.2 \mathrm{~Hz}, 1 \mathrm{H}, H_{\mathrm{NHC}}\right), 8.19-8.11(\mathrm{~m}$, $\left.2 \mathrm{H}, H_{\mathrm{py}}\right), 7.90\left(\mathrm{~d}, J=8.2 \mathrm{~Hz}, 1 \mathrm{H}, H_{\mathrm{py}}\right), 7.75-7.70\left(\mathrm{~m}, 2 \mathrm{H}, H_{\mathrm{py}}\right.$ and $\left.H_{\mathrm{NHC}}\right), 7.58\left(\mathrm{~d}, J=2.1 \mathrm{~Hz}, 1 \mathrm{H}, H_{\mathrm{NHC}}\right), 7.49\left(\mathrm{~d}, J=7.9 \mathrm{~Hz}, 1 \mathrm{H}, H_{\mathrm{py}}\right)$, $7.41\left(\mathrm{t}, J=6.7 \mathrm{~Hz}, 1 \mathrm{H}, H_{\mathrm{py}}\right), 7.34\left(\mathrm{~d}, J=2.1 \mathrm{~Hz}, 1 \mathrm{H}, H_{\mathrm{NHC}}\right), 6.44(\mathrm{~s}$, $\left.2 \mathrm{H}, \mathrm{CH}_{2}\right), 3.72\left(\mathrm{br}, 2 \mathrm{H}, \mathrm{CH}_{\mathrm{Cy}}\right), 3.51-3.43\left(\mathrm{~m}, 1 \mathrm{H}, \mathrm{CH}_{\mathrm{Cy}}\right), 1.77-1.70$ (m, 2H CH $\mathrm{CH}_{2, \mathrm{Cy}}$ ), 1.61-1.47 (m, 9H $\left.\mathrm{CH}_{2, \mathrm{Cy}}\right), 1.42-1.06(\mathrm{~m}, 19 \mathrm{H}$ $\left.\mathrm{CH}_{2, \mathrm{Cy}}\right) \cdot{ }^{13} \mathrm{C}\left\{{ }^{1} \mathrm{H}\right\}$ NMR (125.83 MHz, MeCN- $\left.d_{3}\right): \delta$ 201.6, 182.1, 153.7, 153.5, 153.2, 150.9, 141.9, 140.5, 126.8, 126.7, 125.0, 124.5, 124.1, 124.0, 119.8, 113.3, 63.8, 56.5, 55.6, 33.5, 32.2 (2C), 25.3 (2C), 24.3, 22.4. IR $\left(\mathrm{cm}^{-1}\right): \nu(\mathrm{C} \equiv \mathrm{N})$ 2168. MS-ESI $(\mathrm{m} / \mathrm{z}):\left[3 \mathbf{b}-\mathrm{PF}_{6}\right]^{+}$ calcd, 830.29; found, 829.94. Anal. calcd for $\mathrm{C}_{38} \mathrm{H}_{47} \mathrm{~F}_{12} \mathrm{FeN}_{9} \mathrm{P}_{2}$ : C, 46.78; H, 4.86; N, 12.92. Found: C, 47.16; H, 4.71; N, 12.76 .
4b-[Fe(NCC)(CNBn $\left.)_{3}\right]\left(\mathbf{P F}_{6}\right)_{2}$. $102 \mathrm{mg}, 15 \%$ yield. ${ }^{1} \mathrm{H}$ NMR $\left(400.13 \mathrm{MHz}, \mathrm{MeCN}-d_{3}\right): \delta 8.56\left(\mathrm{~d}, J=4.8 \mathrm{~Hz}, 1 \mathrm{H}, o-H_{\mathrm{py}}\right), 8.20(\mathrm{~d}$, $\left.J=2.2 \mathrm{~Hz}, 1 \mathrm{H}, H_{\mathrm{NHC}}\right), 8.08-8.03\left(\mathrm{~m}, 1 \mathrm{H}, H_{\mathrm{py}}\right), 7.98(\mathrm{~d}, J=5.6 \mathrm{~Hz}$, $\left.1 \mathrm{H}, H_{\text {py }}\right), 7.92-7.87\left(\mathrm{~m}, 1 \mathrm{H}, H_{\mathrm{py}}\right), 7.84\left(\mathrm{~d}, J=8.2 \mathrm{~Hz}, 1 \mathrm{H}, H_{\mathrm{py}}\right)$, $7.73\left(\mathrm{~d}, J=2.2 \mathrm{~Hz}, 1 \mathrm{H}, H_{\mathrm{NHC}}\right), 7.57$ (d, $J=2.1 \mathrm{~Hz}, 1 \mathrm{H}, H_{\mathrm{NHC}}$ ), 7.55-7.52 (m, $\left.1 \mathrm{H}, H_{\mathrm{py}}\right), 7.41-7.29\left(\mathrm{~m}, 10 \mathrm{H}, H_{\mathrm{Bn}}\right.$ and $\left.H_{\mathrm{NHC}}\right), 7.26-$ $7.24\left(\mathrm{~m}, 3 \mathrm{H}, H_{\mathrm{Bn}}\right.$ and $\left.H_{\mathrm{py}}\right), 7.10-7.06\left(\mathrm{~m}, 1 \mathrm{H}, H_{\mathrm{py}}\right), 6.99-6.97(\mathrm{~m}$, $\left.4 \mathrm{H}, H_{\mathrm{Bn}}\right), 6.39$ (s, 2H, CH$\left.H_{2}\right), 4.66\left(\mathrm{~s}, 6 \mathrm{H}, \mathrm{CH}_{2, \mathrm{Bn}}\right) .{ }^{13} \mathrm{C}\left\{{ }^{1} \mathrm{H}\right\} \mathrm{NMR}$ $\left(125.83 \mathrm{MHz}, \mathrm{MeCN}-d_{3}\right): \delta$ 200.2, 196.0, 181.2, 154.1, 153.6, $153.0,150.8,141.8,140.4,134.1,133.8,130.2,130.0,129.7$, $129.4,128.2$, 127.5, 127.0, 126.6, 125.0, 124.5, 124.3, 123.6, 119.8, 113.3, 63.8, 50.0, 49.0. IR $\left(\mathrm{cm}^{-1}\right): \nu(\mathrm{C} \equiv \mathrm{N})$ 2177. MS-ESI $(\mathrm{m} / \mathrm{z}):\left[\mathbf{4 b}-2 \mathrm{PF}_{6}\right]^{2+}$ calcd, 354.62; found, 354.37. Anal. calcd for $\mathrm{C}_{41} \mathrm{H}_{35} \mathrm{~F}_{12} \mathrm{FeN}_{9} \mathrm{P}_{2}$ : C, 49.27; H, 3.53; N, 12.61. Found: C, 48.98; H, $3.56 ; \mathrm{N}, 12.47$.

5b-[Fe(NCC)(CN-p-PhOMe $\left.)_{3}\right]\left(\mathbf{P F}_{\mathbf{6}}\right)_{2} .89 .8 \mathrm{mg}, 60 \%$ yield. ${ }^{1} \mathrm{H}$ NMR (400.13 MHz, MeCN- $\left.d_{3}\right): \delta 8.53\left(\mathrm{~d}, J=3.3 \mathrm{~Hz}, 1 \mathrm{H}, o-H_{\mathrm{py}}\right)$, $8.44\left(\mathrm{~d}, J=4.9 \mathrm{~Hz}, 1 \mathrm{H}, H_{\mathrm{py}}\right), 8.28\left(\mathrm{~s}, 1 \mathrm{H}, H_{\mathrm{NHC}}\right), 8.12(\mathrm{t}, J=7.5$ $\left.\mathrm{Hz}, 1 \mathrm{H}, H_{\mathrm{py}}\right), 7.92\left(\mathrm{~d}, J=8.4 \mathrm{~Hz}, 1 \mathrm{H}, H_{\mathrm{py}}\right), 7.81-7.76\left(\mathrm{~m}, 2 \mathrm{H}, H_{\mathrm{py}}\right.$ and $\left.H_{\mathrm{NHC}}\right), 7.63\left(\mathrm{~s}, 1 \mathrm{H}, H_{\mathrm{NHC}}\right), 7.54\left(\mathrm{~d}, J=7.7 \mathrm{~Hz}, 1 \mathrm{H}, H_{\mathrm{py}}\right), 7.37-$ $7.24\left(\mathrm{~m}, 8 \mathrm{H}, H_{\mathrm{NHC}}, H_{\mathrm{py}}\right.$, and $\left.H_{\mathrm{Ar}}\right), 7.13-7.10\left(\mathrm{~m}, 1 \mathrm{H}, H_{\mathrm{py}}\right), 0.7 .01$ $\left(\mathrm{d}, J=8.4 \mathrm{~Hz}, 2 \mathrm{H}, H_{\mathrm{Ar}}\right), 6.91\left(\mathrm{~d}, J=8.5 \mathrm{~Hz}, 4 \mathrm{H}, H_{\mathrm{Ar}}\right), 6.56(\mathrm{~s}, 2 \mathrm{H}$, $\mathrm{CH}_{2}$ ), $3.89\left(\mathrm{~s}, 3 \mathrm{H}, \mathrm{OCH}_{3}\right), 3.78\left(\mathrm{~s}, 6 \mathrm{H}, \mathrm{OCH}_{3}\right) .{ }^{13} \mathrm{C}\left\{{ }^{1} \mathrm{H}\right\} \mathrm{NMR}$ (125.83 MHz, MeCN- $\left.d_{3}\right): \delta 189.1,179.1,161.3$ (2C), 155.0, 153.6, $153.0,150.7,141.9,140.4,129.4,129.0,126.8,126.7,125.4$, 124.6, 124.0, 123.9, 120.0, 115.6 (2C), 113.5, 64.0, 56.6, 56.5. IR $\left(\mathrm{cm}^{-1}\right): \nu(\mathrm{C} \equiv \mathrm{N})$ 2135. MS-ESI $(\mathrm{m} / \mathrm{z}):\left[5 \mathbf{b}-\mathrm{PF}_{6}\right]^{+}$calcd, 902.19; found, 901.95.

\section{Conclusions}

Addition of substituted isocyanides to a solution of the $\mathrm{Fe}$ (II) NHC complex 1 with trans labile sites leads to the syntheses of isocyanide-substituted $\mathrm{Fe}(\mathrm{II})$ complexes $\mathbf{3 a - 5 a}$ and $\mathbf{2 b - 5 \mathbf { b } .}{ }^{t} \mathrm{Bu}$, $\mathrm{Cy}, \mathrm{Bn}$, and $p$-PhOMe were used as substituents on the isocyanide moiety. Characterization of the products by NMR spectroscopy and single crystal X-ray diffraction (SC-XRD; for $\mathbf{3 a}, \mathbf{4 a}, \mathbf{2 b}, \mathbf{3 b}$, and $\mathbf{5 b}$ ) reveals mono(isocyanide) substitution or tri(isocyanide) substitution depending on the relative amount of isocyanide used for the syntheses. Isolation of di(isocyanide)substituted products is not possible, as the addition of 2 equiv. isocyanide to 1 results in a mixture of mono- and tri-substituted complexes. The molecular structures of the tri-substituted complexes obtained by SC-XRD show meridional coordination of the three isocyanides and a change from an equatorial, fourfold coordination to a meridional, threefold coordination of the polydentate NCCN ligand. ${ }^{1} \mathrm{H}$ NMR spectroscopy was applied to monitor the reaction of 1 with an excess of $\mathrm{CN}^{t} \mathrm{Bu}(5$ equiv.). Within $40 \mathrm{~min}$ an intermediate species is amounting to $73 \%$ before reacting to the tri-substituted complex $\mathbf{2 b}$. Based on the NMR data the intermediate can be identified as di(isocyanide)-substituted derivative $2 \mathrm{c}$ of complex 1 . In $2 \mathrm{c}$ one pyridyl moiety of the NCCN ligand has been removed from the coordination sphere and a cis coordination of the two isocyanide ligands is observed. Cyclic voltammetry experiments on all compounds reveal a significantly increased half-cell potential for the fully reversible redox step $\mathrm{Fe}(\mathrm{II}) / \mathrm{Fe}(\mathrm{III})$ of mono- 
substituted complexes 2a-5a (up to $573 \mathrm{mV}$ versus $\mathrm{Fc} / \mathrm{Fc}^{+}$) compared to starting complex $1(423 \mathrm{mV})$. The tri-substituted complexes $\mathbf{2 b} \mathbf{- 5 b}$ required a further increase in potential up to $1092 \mathrm{mV}$ for the oxidation to $\mathrm{Fe}(\mathrm{III})$, albeit this redox step is found to be irreversible. The presented structural and analytical data can be used as a starting point for further modification of the $\mathrm{Fe}(\mathrm{II})$ complexes by adjusting the isocyanide substituents in terms of steric demand or $\sigma$-donor $/ \pi$-acceptor ratio.

\section{Acknowledgements}

The authors gratefully acknowledge support by the TUM graduate school. A. C. L. further appreciates the financial support by the Fonds der Chemischen Industrie (FCI). S. H. thanks Tassilo M. F. Restle for his valuable contributions.

\section{References}

1 I. Bauer and H.-J. Knölker, Chem. Rev., 2015, 115, 3170-3387.

2 K. Gopalaiah, Chem. Rev., 2013, 113, 3248-3296.

3 S. Blanchard, E. Derat, M. Desage-El Murr, L. Fensterbank, M. Malacria and V. Mouriès-Mansuy, Eur. J. Inorg. Chem., 2012, 376-389.

4 K. Junge, K. Schröder and M. Beller, Chem. Commun., 2011, 47, 4849-4859.

5 A. Fürstner, Angew. Chem., Int. Ed., 2009, 48, 1364-1367.

6 S. Enthaler, K. Junge and M. Beller, Angew. Chem., Int. Ed., 2008, 47, 3317-3321.

7 B. D. Sherry and A. Fürstner, Acc. Chem. Res., 2008, 41, 15001511.

8 K. Riener, S. Haslinger, A. Raba, M. P. Högerl, M. Cokoja, W. A. Herrmann and F. E. Kühn, Chem. Rev., 2014, 114, 5215-5272.

9 T. Punniyamurthy, S. Velusamy and J. Iqbal, Chem. Rev., 2005, 105, 2329-2364.

10 E. C. Theil and D. J. Goss, Chem. Rev., 2009, 109, 4568-4579.

11 K. Ray, F. F. Pfaff, B. Wang and W. Nam, J. Am. Chem. Soc., 2014, 136, 13942-13958.

12 A. B. McQuarters, M. W. Wolf, A. P. Hunt and N. Lehnert, Angew. Chem., Int. Ed., 2014, 53, 4750-4752.

13 L. Que and W. B. Tolman, Nature, 2008, 455, 333-340.

14 W. Nam, Y. Ryu and W. Song, JBIC, J. Biol. Inorg. Chem., 2004, 9, 654-660.

15 K. P. Bryliakov and E. P. Talsi, Coord. Chem. Rev., 2014, 276, 73-96.

16 S. Bang, S. Park, Y.-M. Lee, S. Hong, K.-B. Cho and W. Nam, Angew. Chem., Int. Ed., 2014, 53, 7843-7847.

17 B. J. Wallar and J. D. Lipscomb, Chem. Rev., 1996, 96, 26252658.

18 E. P. Talsi and K. P. Bryliakov, Coord. Chem. Rev., 2012, 256, 1418-1434.
19 D. J. Nelson, Eur. J. Inorg. Chem., 2015, 2012-2027.

20 M. N. Hopkinson, C. Richter, M. Schedler and F. Glorius, Nature, 2014, 510, 485-496.

21 L.-A. Schaper, S. J. Hock, W. A. Herrmann and F. E. Kühn, Angew. Chem., Int. Ed., 2013, 52, 270-289.

22 F. E. Hahn and M. C. Jahnke, Angew. Chem., Int. Ed., 2008, 47, 3122-3172.

23 Y. Hitomi, K. Arakawa and M. Kodera, Chem.-Eur. J., 2013, 19, 14697-14701.

24 T. Chantarojsiri, Y. Sun, J. R. Long and C. J. Chang, Inorg. Chem., 2015, 54, 5879-5887.

25 S. Bandyopadhyay, A. Rana, K. Mittra, S. Samanta, K. Sengupta and A. Dey, Inorg. Chem., 2014, 53, 10150-10158.

26 A. Raba, M. Cokoja, S. Ewald, K. Riener, E. Herdtweck, A. Pöthig, W. A. Herrmann and F. E. Kühn, Organometallics, 2012, 31, 2793-2800.

27 A. Raba, M. Cokoja, W. A. Herrmann and F. E. Kühn, Chem. Commun., 2014, 50, 11454-11457.

28 J. W. Kück, A. Raba, I. I. E. Markovits, M. Cokoja and F. E. Kühn, ChemCatChem, 2014, 6, 1882-1886.

29 S. Haslinger, A. Raba, M. Cokoja, A. Pöthig and F. E. Kühn, J. Catal., 2015, 331, 147-153.

30 S. Haslinger, J. W. Kück, E. M. Hahn, M. Cokoja, A. Pöthig, J.-M. Basset and F. E. Kühn, Inorg. Chem., 2014, 53, 1157311583.

31 J. Rieb, A. Raba, S. Haslinger, M. Kaspar, A. Pöthig, M. Cokoja, J.-M. Basset and F. E. Kühn, Inorg. Chem., 2014, 53, 9598-9606.

32 M. R. Anneser, S. Haslinger, A. Pöthig, M. Cokoja, J.-M. Basset and F. E. Kühn, Inorg. Chem., 2015, 54, 37973804.

33 A. E. Carpenter, C. C. Mokhtarzadeh, D. S. Ripatti, I. Havrylyuk, R. Kamezawa, C. E. Moore, A. L. Rheingold and J. S. Figueroa, Inorg. Chem., 2015, 54, 2936-2944.

34 H.-K. Kim, J.-H. Lee, Y.-J. Kim, Z. Nu Zheng and S. W. Lee, Eur. J. Inorg. Chem., 2013, 4958-4969.

35 L. Weber, Angew. Chem., Int. Ed., 1998, 37, 1515-1517.

36 Y. Yamamoto, Coord. Chem. Rev., 1980, 32, 193-233.

37 F. A. Cotton and F. Zingales, J. Am. Chem. Soc., 1961, 83, 351355.

38 M. V. Barybin, Coord. Chem. Rev., 2010, 254, 1240-1252.

39 L. A. Labios, M. D. Millard, A. L. Rheingold and J. S. Figueroa, J. Am. Chem. Soc., 2009, 131, 11318-11319.

40 J. J. Scepaniak, R. P. Bontchev, D. L. Johnson and J. M. Smith, Angew. Chem., Int. Ed., 2011, 50, 6630-6633.

41 A. Raba, M. R. Anneser, D. Jantke, M. Cokoja, W. A. Herrmann and F. E. Kühn, Tetrahedron Lett., 2013, 54, 3384-3387.

42 N. G. Connelly and W. E. Geiger, Chem. Rev., 1996, 96, 877910. 